\title{
Spiritual Journey Principles in Javanese House: an Interdisciplinary Reading
}

\author{
Pudji Pratitis Wismantara \\ Department of Architecture, Faculty of Science and Engineering \\ The State Islamic University of Maulana Malik Ibrahim, Malang \\ Phone:085755218635, email: vismantara@yahoo.co.id
}

\section{Abstrak}

Upaya rekontekstualisasi dimulai dengan merumuskan karakter dasar dan dilanjutkan dengan membangun rancangan arsitekturalnya. Tujuan paper ini adalah untuk mengeksplorasi dan merekontekstualisasi karakter dasar pada Rumah Adat Jawa. Model pengkajiannya menggunakan metode visual culture, sebagai model pembacaan menyeluruh terhadap wujud arsitektur dan substansi di baliknya, dengan menyertakan pendekatan antardisiplin keilmuan. Langkah pertama, melacak kesepadanan ungkapan pemikiran antara Rumah Adat Jawa dengan Arsitektur lain di wilayah Nusantara, seperti Aceh, Toraja, dan Dayak, dengan melakukan pembacaan lintas-kultural. Langkah kedua, mencari korelasi antara Rumah Jawa dengan folklore non-arsitektural, seperti kisah Dewa Ruci dan Serat Jatimurti, dengan melakukan pembacaan lintas-struktural. Dalam proses kajian dapat ditunjukkan bahwa Rumah Adat Jawa memiliki karakter universal Nusantara dan karakter lokal Jawa. Perjenjangan ruang pada Rumah Jawa memiliki keterkaitan dengan konsep perjalanan meniadakan selain Allah, dan perjalanan menuju kepada Allah. Penemuan ungkapan pemikiran, yang merupakan karakter dasar Rumah Jawa ini, setidaknya bisa menjadi landasan pijak dalam mengembangkan arsitektur, yang sesuai dengan konteks ruang (Jawa) dan konteks waktu (kekinian).

Kata kunci: rekontekstualisasi, Nusantara, karakter dasar, perjalanan

Abstract

Re-contextualizing effort is begun by formulating basic character then developing of architectural design. The purpose of this paper is to explore and re-contextualize the basic character of traditional Javanese house. This study used visual culture method as a thorough of the architectural form and substance behind it by including inter-disciplinary scientific approach. The first step is tracing equivalence thought expression among traditional Javanese House and other traditional houses in through Indonesian archipelago, such as Aceh, Toraja, and Dayak, by doing trans-cultural readings. Step two, is finding a relationship between traditional Javanese house with non-architectural folklore, for instance the story of Dewa Ruci and serat Jatimurti, by doing trans-structural readings. In the process of study, it is seen that traditional Javanese house is consist of universal characters and Javanese local characters. The structural space on the traditional Javanese house is relevance to the concept of Islamic journey that negating god other than Allah, 
and travelling towards Allah. The discovery of the thought expression which is the basic character of this traditional Javanese house, at least, can be a starting point in developing an architecture which is suitable for the space context (of Java) and time context (present).

Key words: recontextualise, Archipelago, basic character, journey

\section{Introduction}

Studies of Javanese House rather than to return to the past. Javanese House will die if they are standardized and frozen as a "heritage" tradition that should never be changed. This study seeks to build together a starting point for better sustainability in Archipelago Architecture. Sustainability efforts this architecture must consider the context of the Archipelago space and the present time, so need a more relevant term: recontextualise architecture.

The main steps that need to be done is an attempt to rediscover and develop the basic character of Javanese House. Basic character of the architecture is an expression of thought consisting of philosophy, concepts, and form. Basic character is required to develop or maintain the existence of an architecture. The basic character is obtained from different depths, namely [1] of the most visible characteristics such as morphology (figure-silhouette, material, or memories of the elements of the building). [2] the concepts of architectural space and all of its local traditions. Also from, [3] realized from his philosophy, (Pangarsa, 2011: 6). For example, the value of community mutual cooperation (gotong-royong) or ecology behind their existence.

The purpose of this paper is to explore and contextualise the basic character of the Javanese House. To develop the Javanese House in accordance with the current context, it should be "read" characters essentially critical, and "re-write" the basic character of the new design. The study of Javanese House here using visual culture method, as a model of thorough reading of the architectural form and substance behind it, to include inter-disciplinary scientific approach. The first step, the expression of thought trace equivalence between Javanese House with other Houses in Archipelago, such as Aceh, Toraja, and Dayak, by doing cross-cultural readings. This reading serves to find the basic character of the universality of Archipelago. The second step, to find the relationship between Javanese House with non-architectural folklore, like the story of Dewa Ruci and the literature of Serat Jatimurti, by doing cross-structural readings. In the process of reading can be shown that the Javanese House has a universal character of Archipelago in 
cross-cultural readings, and the local character of Java on the cross-structural readings. This reading serves to find the basic character of the Javanese locality.

\section{La Ilaha Ilallah as the Concept of Javanese House}

The division of space at Javanese House (which consists of pendhapa pringgitan, dalem, and krobongan), Javanese interpreted as the sangkan-paran journey (Hidayat, 2009: II-5). This is shown by the division of the hierarchy in the primary structure of space (pendhapa, pringgitan, dalem, krobongan), which has the characteristic differences between each other. Sangkan-paran concept here means the direction of coming and going, which has a point of origin and a point of destination. In the wisdom of Java, this concept likens man who was traveling. In everyday activities, humans do not live permanently along the trajectory path (pendhapa, pringgitan, dalem, krobongan). Space trajectory is only enabled for daily activities which are temporary and not to live (dwell). Activities reside (dwell) permanently in gandok area, who are on the side or back of dalem area.

Sangkan-paran journey is a journey towards Allah The Almighty. It is appropriate if the trip is to use the principle of La Illaha illallah. La Illaha principle has a meaning that is not god everywhere. In this life no one deserves to be a god, do not have the eligibility to uphold the highest, to be defended to the death: the king, power, property, objects, etc (Nadjib, 2005: 14). Illallah principle means only Allah the Almighty, who has the position, strength, and function like that. Javanese house represents remembrance of Allah Almighty (tauhid) in the behavior of human life.

Symbolization of the human journey at Javanese House, indicated by the change of space in a hierarchical manner, from pendhapa (which represents the material world) to krobongan (which represents the spiritual world). Pendhapa was in the front area, is open and bright, and connect with the outside environment. Pendhapa is a place of daily activities. Krobongan located in the rear, is closed and dark, and separately with the external environment. Krobongan is a place of exile, where the Javanese communicate with God: Allah.

This process takes place in this spiritual journey back and forth, not just the beginning of pendhapa and ends at krobongan. After the Javanese received inspiration (ilham) from Allah, received enlightenment, he must go back to the real world and the practice of spirituality into the 
world. After humans are at a more mature level of religiosity, he could only alienate themselves in seclusion, he must go down to the community as a fellow helper (Mangunwijaya, 1992: 29).

\section{Universality of Archipelago in Reading Cross-Cultural}

The efforts to recontextualise Javanese House began by formulating basic character and continued with the development of architectural design. There are two aspects inherent in the basic character of architecture, namely universality and locality. Aspect of universality in the context of Archipelago Architecture is a common aspect which becomes the main character to the overall architecture of Archipelago cultural space. While aspects of the locality is a specific tendency to force the character of each local architecture in Archipelago cultural space.

The main characteristic of Archipelago Architecture shows the openness of the society in the outside area and the intimacy of family covered in the inside area. Every house in the context of Archipelago requires integration between private and public life, vertical and horizontal, or sacred and profane. The principle of combining these two elements are complementary (to borrow a term from Jo Santosa, 2009: 40-42) called the principle of microcosmic-dualities. Every house in the scope of Archipelago cultural space is divided into two regions, namely the front and rear areas (Santoso, 2000: 19).

Front areas have outward oriented, serves as a shade, not restricted solid wall, resulting in resonant vibrational energy between a person with a place of his feet and its surrounding environment. By occupying the front, one feels controlled and orients itself upon this place and make the boundary with the surrounding environment, which is still visible visually. Rear area has a characteristic orientation into, serves as a protector, and is limited by the solid wall. With this condition, a person who inhabit it can activate the spiritual consciousness. Entering the rear area means break the interaction between the person with the surrounding environment, and simultaneously activate the space spirituality.

The main categorization of social relations is the linkage between the relations, which is oriented outside and inside. The area behind the house is the person to pull himself from personal involvement in the wider world, in order to accumulate power within him. The area front the house is a region-oriented exit where someone involves himself in social relationships with others, in order to position themselves relative status with others. 
Javanese house which is divided into four basic structures (pendhapa, pringgitan, dalem, and krobongan), also based on the principle of microcosmic-dualities. The front area which consists of pendhapa and pringgitan have an outward-oriented and connected with the outside environment. These areas are public and formal, marked by elements of open space, shaded, roof, and without walls. This area is generally used for daily activity that symbolized the transience. Rear area consisting of delem and krobongan oriented inward and separately with the external environment. This area is private and intimate, characterized by an enclosed space, protected, roofed, and walled. This area is generally used for storage activities, including storage of the body during sleep.

Table 1: Significant differences between Front Area and Rear Area at Javanese House (Wismantara, 2011)

\begin{tabular}{|c|c|c|c|}
\hline Pendhapa & Pringgitan & Dalem & Krobongan \\
\hline \multicolumn{2}{|c|}{ front area } & \multicolumn{2}{|c|}{ Rear area } \\
\hline \multicolumn{2}{|c|}{ outward oriented } & \multicolumn{2}{|c|}{ inward oriented } \\
\hline \multicolumn{2}{|c|}{ open, shaded, roofed, without walls } & \multicolumn{2}{|c|}{ enclosed, protected, roofed, walled } \\
\hline \multicolumn{2}{|c|}{ connected with the external environment } & \multicolumn{2}{|c|}{ separately with the external environment } \\
\hline \multicolumn{2}{|c|}{ public and formal } & \multicolumn{2}{|c|}{ private and intimate } \\
\hline \multicolumn{2}{|c|}{ symbol of transience } & \multicolumn{2}{|c|}{ symbol of eternity } \\
\hline
\end{tabular}

If the Javanese Architecture has a horizontal character (marked with a blend of the front and rear areas), not so with some Archipelago houses such as in Aceh, Dayak, and Toraja, a vertical character. This image is characterized by a combination of pit and stage. Stage presence cannot be separated by a blank space underneath, called the pit. Pit has a characteristic outwardoriented, and connected with the outside environment. This area is public and formal, marked by elements of open space, shaded, roof (floor of the stage), and without walls (Hidayat, 2002: IX5). This area is generally used for daily activity that symbolized the transience. Stage area has a characteristic inward and separately with the external environment. This area is private and intimate, characterized by an enclosed space, protected, roofed, and walled. This area is generally used for storage activities, including storage of the body during sleep. So it can be concluded that despite having a different image, horizontal and vertical, all the houses in the archipelago has a universal character, in example the principle of microcosmic-dualities.

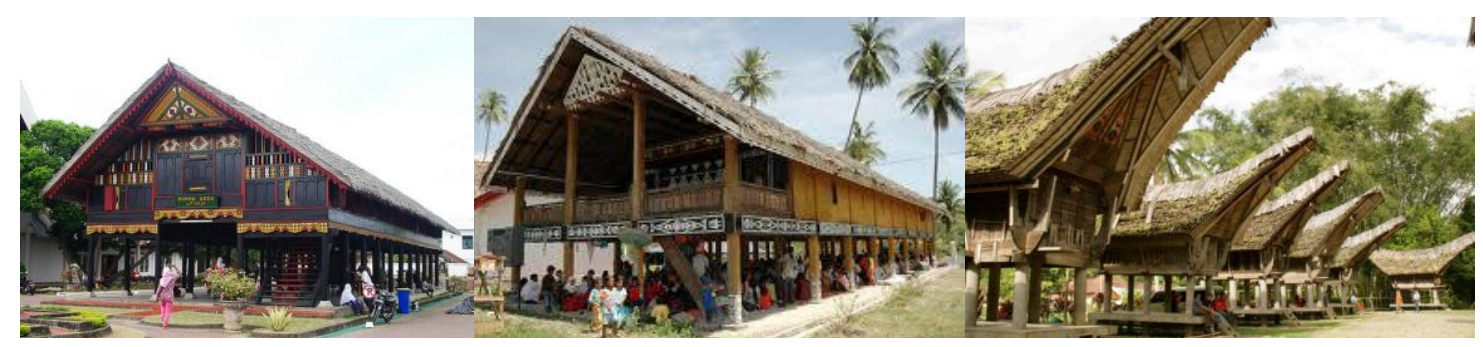


Figure 1: Universal Character of the Microcosmic-dualities on the Aceh, Dayak, and Toraja House (www.photobucket.com, 2011)

\section{Locality of Java in Reading Cross-Structural}

The next efforts to recontextualize Javanese House is to formulate basic character that is local and specific. In the Javanese knowledge system, the architecture is one of a powerful medium for expressing thoughts that Javanese perspective. To determine the expression of thought (basic character) which is a "narrative unreadable", in reading Javanese House is required interpretation (Prijotomo, 2004b: 27). To explore the basic character of Javanese House, it is necessary first track on the connection between Javanese Architecture with non-architectural folklore, like the story of Dewa Ruci and Serat Jatimurti, by doing cross-structural readings. In synchronic, the development of Javanese Architecture have simultaneous connection with the development of Javanese folklore, since both are in a large system the same thing: Javanese Knowledge.

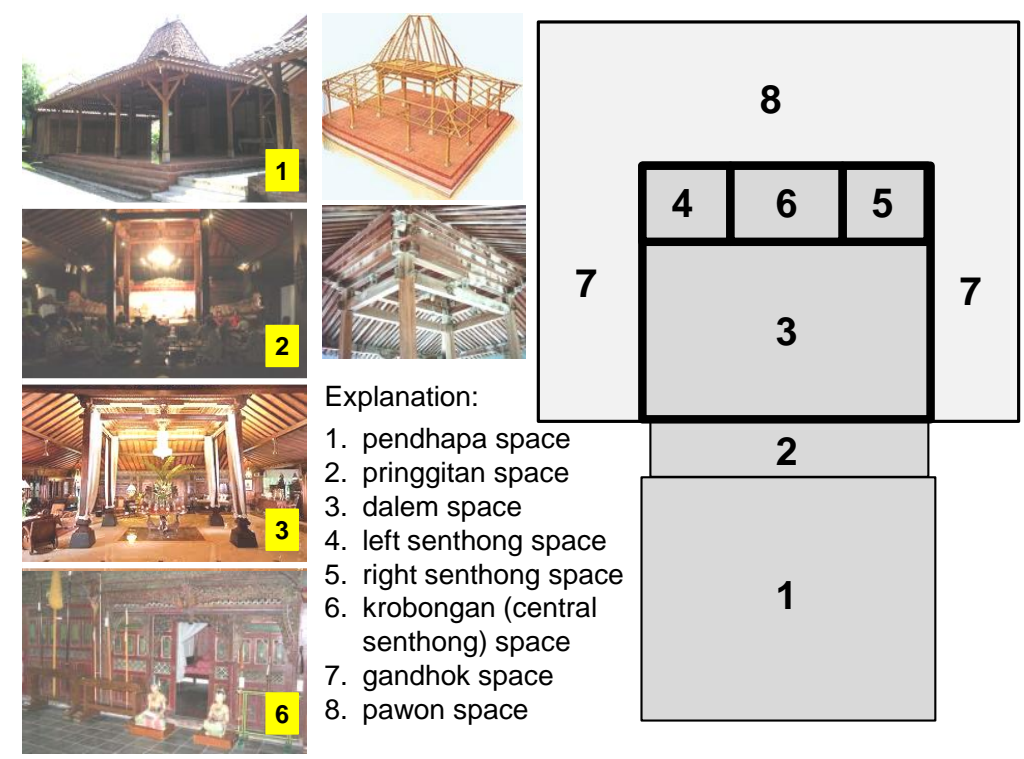

Figure 2: Basic Structures on Javanese Architecture (Wismantara, 2011)

\section{Javanese House as a Way}

Javanese house with four basic structures (pendhapa, pringgitan, dalem, and krobongan) showing appreciation for a journey. Javanese house can be described as a way to pass. In 
pendhapa zone, there is rong-rongan which is a space formed inside the main column (sakaguru) which leads to the top (tumpangsari). Rong-rongan interpreted not as the real of rong. In pendhapa zone, the presence of rong-rongan interpreted as a "remembrance" will be the dimensions of verticality when we travel horizontally (from pandhapa to krobongan). When entering the pringgitan zone, we see "the selamatangkep door", a narrow hallway that symbolizes the transition process on the jouney. Transition is interpreted as a process of change for the better to renounce worldly lust or material desires.

When entering dalem zone, we see again rong-rongan. This element also has a meaning as a "remembrance" will be the dimensions of verticality when we travel horizontally. After arriving in krobongan zone, then we find the actual rong. Rong is the Javanese space concept which has infinite-dimensional, meaningful as well as spiritual space, which stripped material and contains the energy of the Godhead. Rong is space journey. That is, if life is a journey, then the space (in Javanese House) should also be understood as a way, a place where people continually pass through (Hidayat, 2009: II-9).

Table 2: Javanese House as a Way (Wismantara, 2011)

\begin{tabular}{|c|c|c|c|}
\hline Pendhapa & Pringgitan & Dalem & Krobongan \\
\hline rong-rongan & selamatangkep door & rong-rongan & (sa-)rong \\
\hline \multicolumn{3}{|c|}{ Horizontally } & vertically \\
\hline \multicolumn{3}{|c|}{ matter (lahiriyah) } & $\begin{array}{c}\text { energy } \\
\text { (batiniyah) }\end{array}$ \\
\hline \multicolumn{3}{|c|}{ La Illaha } & Illallah \\
\hline
\end{tabular}




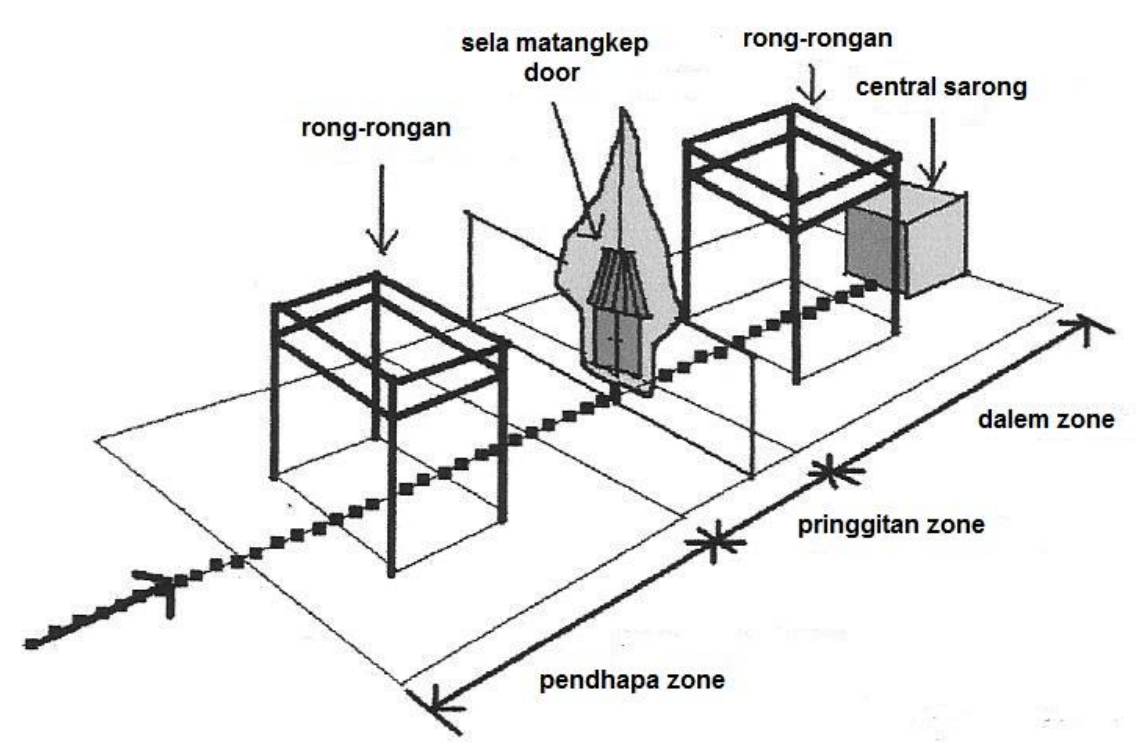

Figure 3: Javanese House as a Way (Hidayat, 2010)

\section{Javanese House and Serat Jatimurti}

Javanese house has a relationship (or similar) model of meaning with Serat Jatimurti. These serat contain about space conceptions in the perspective of Javanese knowledge. There are four elements (or nature) forming the space, namely garis (line), lumah (field), jirim (volume), and kajaten (spiritual space). The basic structure of the Javanese House, which consists of pendhapa, pringgitan, dalem, and krobongan, has been linked in parallel with Jatimurti. Pendhapa parallel to garis (line), which in its architecture to explore the wooden columns (saka) are allowed to show the line. Pringgitan parallel with lumah, because pringgitan is puppet (wayang kulit) which only had raen (two-dimensional faces) as lumah. Dalem parallel with jirim, as giriraya (big mountain) which form the hollow volume that looks real. Krobongan (senthong) parallel with kajaten. Krobongan is kajaten that manifests itself, which had been his architecture, was in-space out (Hidayat , 2010: IV-5).

The garis-lumah-jirim element and the pendhapa-pringgitan-dalem element are finitedimensionals, because they can be recognized manifestations and has a material nature. Kajaten and architectural elements: krobongan or senthong is a "supra-volume", a form of infinite space, because the intangible energy that transcends the material and has a spiritual nature. The structure of space on the Javanese House and the four elements in Jatimurti have relevance to the 
concept of journey. La Illaha illallah principle refers to the journey to tackle the material, the journey that negate other than Allah, and the journey towards Allah.

Table 3: The comparison between Jatimurti, with the Structure of the Main Javanese House (Wismantara, 2011)

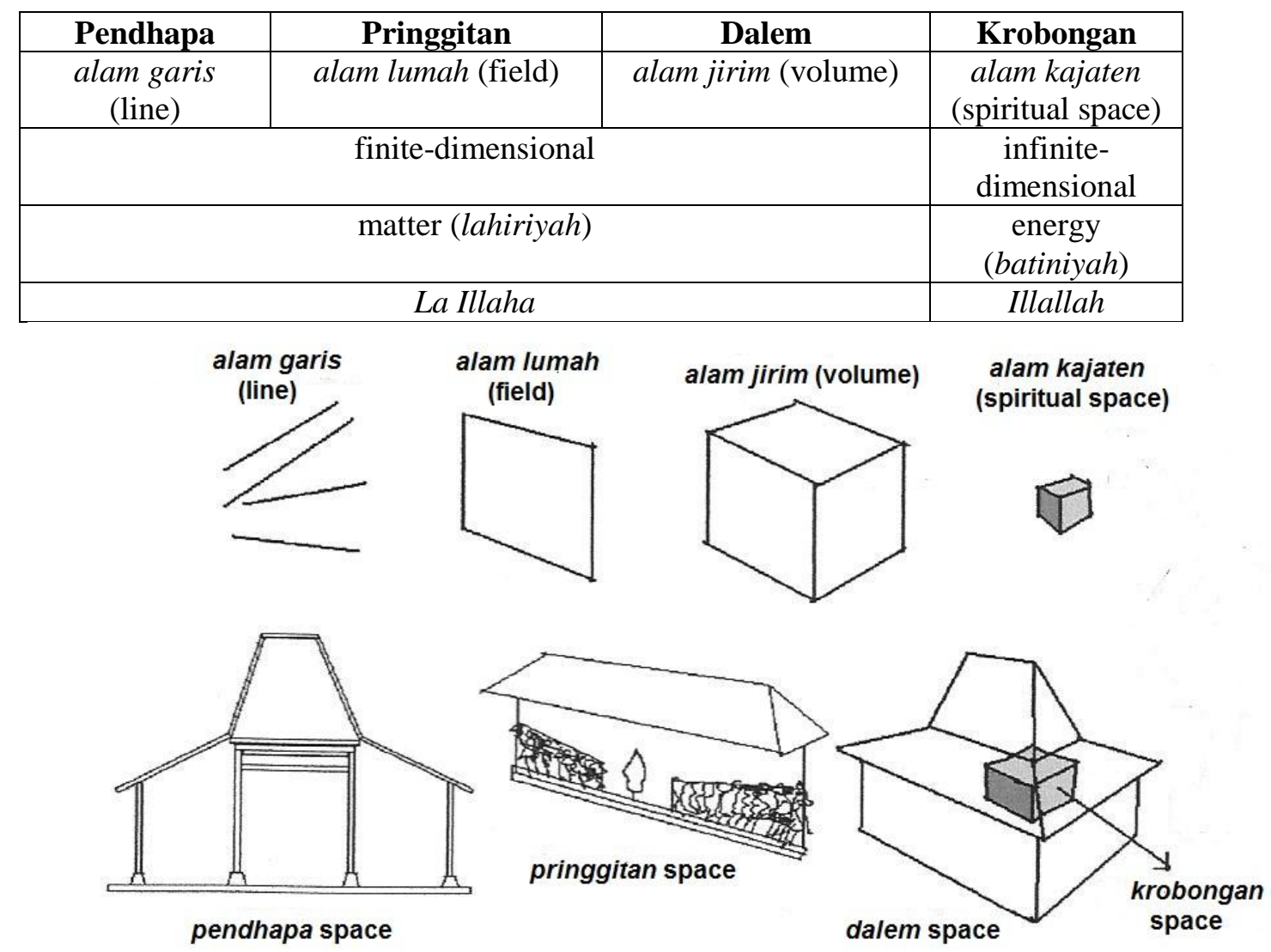

Figure 4: Parallel Comparison Between Javanese House and Serat Jatimurti (Hidayat, 2010)

\section{Javanese House and Dewa Ruci Story}

In teaching about the authenticity of life, Javanese man has a popular myth is Lakon Dewaruci. This myth tells how Bima (the second Pandawa warriors) finds the water of life (tirta Pawitra) at the behest of his teacher, Danghyang Drona. After failing to find water in the woods and mountains, in the end Bima plunge into the ocean to the bottom of the ocean (telenging Samodra) (Aryandini, 2000: 1-3). There Bima met Dewaruci, that his form like Bima but with a much smaller size. Bima was ordered into the body of Dewa Ruci through his left ear, and in it Bima gain experience and doctrine of the authenticity of life. 
Dewaruci story, thus related to the sangkanparan journey concept, as "recorded" in Javanese House. To track its architectural dimension, we need to observe step by step the process of Bima journey, which departs from the palace (the element of origin/start) looking tirta Pawitra (water of life) in telenging samudra. The first step tells Bima who beat two giant among trees in the forest. In the conception of Java, the giant represents the material desires that must be addressed and the trunks of trees represent line elements. The first step is identical to pendhapa space, which is composed of several column (line elements).

The second step tells Bima meets with Hanuman. Hanuman is a figure that is able to mediate two different entities, such as material-spiritual, light-dark, or sacred-profane. Hanuman represents the transition or boundary, which is generally described as an element of the field (lumah). The second step is identical to pringgitan space, which connects between pendhapa (outer space) and dalem (inner space) in Javanese House.

The third step tells Bima who beat the dragon in the ocean. The dragon represents the volume element (jirim). The explanation is, the dragon that moves in a space has a long body proportions, and occupy the starting point (dragon head) and endpoint (dragon tail) on a volume coordinate form (shape space) in a cartesian coordinate system ( $\mathrm{x}, \mathrm{y}, \mathrm{z}$ ). The third step is identical to dalem space, covered by a roof, floor, and walls are massive and in threedimensional space.

Table 4: The comparison between Dewa Ruci Story with the Structure of the Main Javanese House (Wismantara, 2011)

\begin{tabular}{|c|c|c|c|}
\hline Pendhapa & Pringgitan & Dalem & Krobongan \\
\hline $\begin{array}{c}\text { Bima defeat two } \\
\text { giants }\end{array}$ & Bima met Hanuman & $\begin{array}{c}\text { Bima defeat the } \\
\text { dragon }\end{array}$ & $\begin{array}{c}\text { Bima met } \\
\text { Dewa Ruci }\end{array}$ \\
\hline $\begin{array}{c}\text { alam garis } \\
\text { (line) }\end{array}$ & alam lumah (field) & $\begin{array}{c}\text { alam jirim } \\
\text { (volume) }\end{array}$ & alam kajaten \\
\hline \multicolumn{3}{|c|}{ material space } & spiritual space \\
\hline \multicolumn{3}{|c|}{ matter (lahiriyah) } & Illallah \\
\hline
\end{tabular}

The fourth step tells Bima met Dewa Ruci and entered into the body Dewaruci. The unification between Bima and Dewa Ruci represents the element of spiritual space (kajaten), the space has the properties of energy, and overcome the material. This last step shows the 
destruction of the material dimensions of space and the creation of the spiritual dimension of space. The last step is identical to krobongan space in Javanese House.

\section{Contemporary Archipelago Architecture in Writing Contextual}

Designing is the process of translation and development of the basic character of architecture, according to the context of present time and Archipelago space. In the process of reading the above, it can be shown that Javanese House has the universal character of Archipelago in cross-cultural readings, and the local character of Java in cross-structural readings. The discovery of the expression of thought, which is the basic character of this Javanese House, could be a starting point in the "write" a new architecture that fits the context of (Jawa) space and the context of (present) time. One example is the design of Rumah Gunungan Pancasila Plan, which was designed by Rifyal, Mundzir and Ayu (2011: 3), as the students participating in the contest Senvar $12^{\text {nd }}$ in Brawijaya University of Malang.

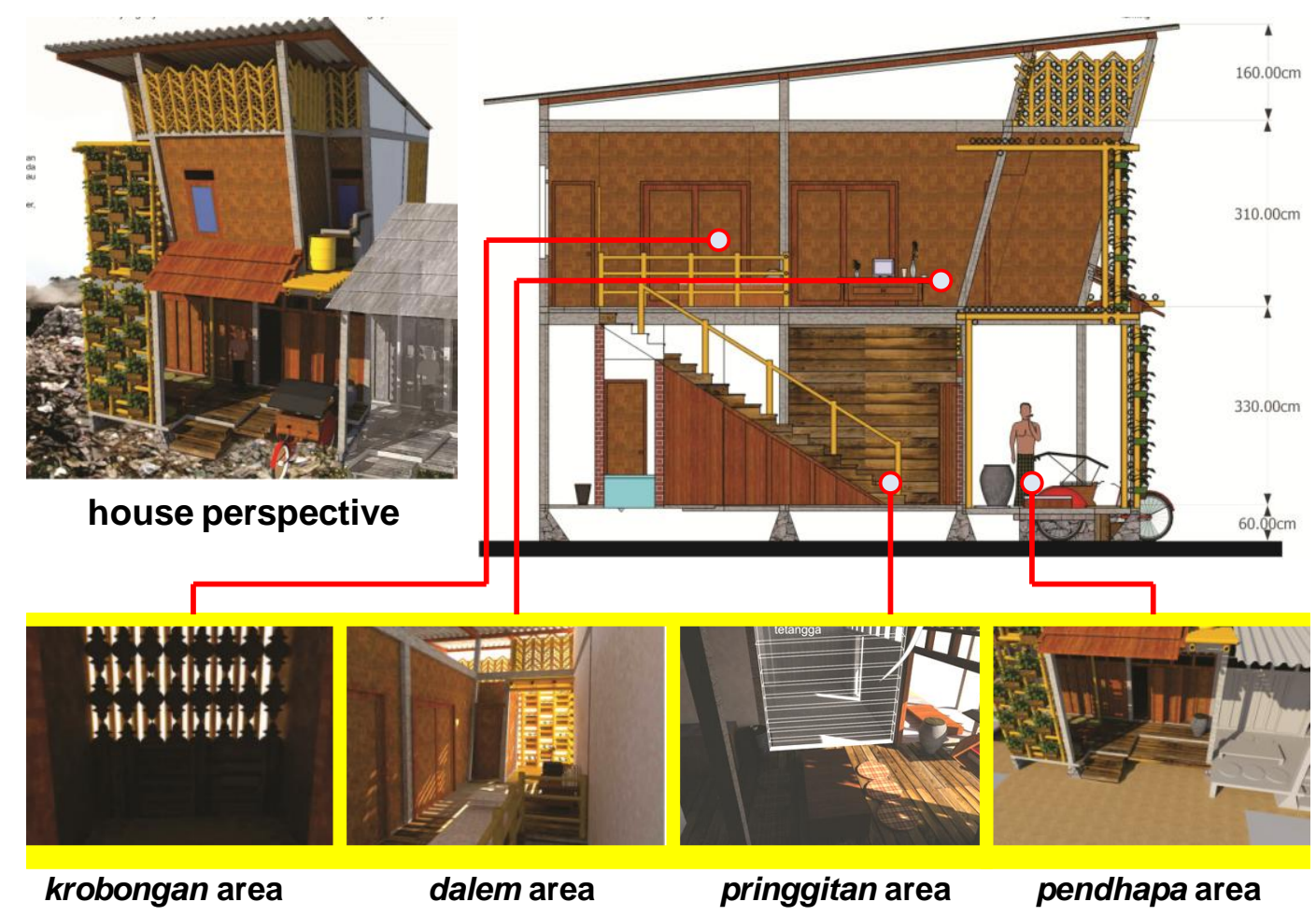

Figure 5: Rumah Gunungan Pancasila Plan (Rifyal, 2011) 
The design seeks to raise the basic character of Javanese House, with a starting point on the universal principles (microcosmic-dualities) and specific principles (La Illaha illallah). The application of universal principles in the design, featuring four basic structures (pendhapa, pringgitan, dalem, and krobongan) in Javanese House. Javanese house that has a horizontal image (marked with a blend of the front and rear areas) transformed into the vertical by using a blend of principle and under the stage. Area under which consisted of pendhapa and pringgitan, have an outward-oriented and connected with the outside environment. These areas are public and formal, marked by elements of open space, shaded, and memorable transparent, "without walls". This area is generally used for daily activity that symbolized the transience. Areas stage consisting of dalem and krobongan, have a separate orientation into the outside environment. This area is private and intimate, characterized by an enclosed space, protected, roofed, and walled. This area is generally used for activities of a privacy.

La Illaha illallah principle applied to the design, presenting gradations of space on the basic structure (pendhapa, pringgitan, dalem, and krobongan) at the Javanese House. We could feel the journey of pendhapa (garis, line), pringgitan (lumah, field), dalem (jirim, volume), up to krobongan (kajaten, spiritual space). Each room has a quality of character as required in the Javanese House, and set the sequence space with gradations of good quality, so that we could feel the impression and atmosphere of sangkan-paran journey.

\section{Conclusion}

Archipelago Architecture recontextualisation is the effort to find the back ("read") the basic character of Javanese House, and developed it ("re-write") in the new architecture design. Basic character is an expression of thought that includes the philosophy, concept, or form. There are two aspects inherent in the basic character of architecture, namely universality and locality. Aspects of universality, in the context of Archipelago Architecture is the main identity for the overall architecture of the Archipelago cultural space. While aspects of locality is a specific identity for each of the local architecture in the Archipelago cultural space.

Recontextualisation is a model of reading and re-writing as a whole on the basic character of the architecture that includes architectural form and substance behind it, to include interdisciplinary scientific approach. How to read and write this, requires a combination of crosscultural and cross-structural paradigm, to get the basic character of a universal as well as locally. 
The discovery of the basic character of architecture, typical of Archipelago, at least, can be a starting point in developing the architecture, which according to the context of Archipelago space and the context of present time it.

Table 5: The final comparison between universality of Archipelago with locality of Jawa in the Javanese House (Wismantara, 2011)

\begin{tabular}{|c|c|c|c|c|c|}
\hline & Pendhapa & Pringgitan & Dalem & Krobongan \\
\hline \multirow{6}{*}{\multicolumn{2}{|c|}{ 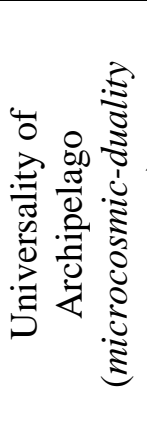 }} & \multicolumn{2}{|c|}{ front area } & \multicolumn{2}{|c|}{ rear area } \\
\hline & & \multicolumn{2}{|c|}{ outward oriented } & \multicolumn{2}{|c|}{ inward oriented } \\
\hline & & \multicolumn{2}{|c|}{$\begin{array}{c}\text { open, } \\
\text { shaded, } \\
\text { roofed, } \\
\text { without walls }\end{array}$} & \multicolumn{2}{|c|}{$\begin{array}{l}\text { protected, } \\
\text { roofed, }\end{array}$} \\
\hline & & \multicolumn{2}{|c|}{$\begin{array}{l}\text { connected with the external } \\
\text { environment }\end{array}$} & \multicolumn{2}{|c|}{ separately with the external environment } \\
\hline & & \multirow{2}{*}{\multicolumn{2}{|c|}{$\begin{array}{l}\text { public and formal } \\
\text { symbol of transience }\end{array}$}} & \multicolumn{2}{|c|}{ private and intimate } \\
\hline & & & & \multicolumn{2}{|c|}{ symbol of eternity } \\
\hline \multirow{13}{*}{ 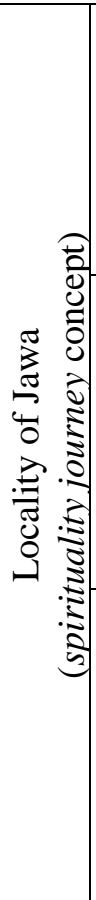 } & \multirow{4}{*}{ 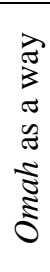 } & rong-rongan & $\begin{array}{c}\text { Selamatangkep } \\
\text { door }\end{array}$ & rong-rongan & (sa-)rong \\
\hline & & \multicolumn{3}{|c|}{ Horizontally } & Vertically \\
\hline & & \multicolumn{3}{|c|}{$\begin{array}{c}\text { matter } \\
\text { (lahiriyah) }\end{array}$} & $\begin{array}{c}\text { energy } \\
\text { (batiniyah) }\end{array}$ \\
\hline & & \multicolumn{3}{|c|}{ La Illaha } & Illallah \\
\hline & \multirow{4}{*}{ - } & $\begin{array}{l}\text { alam garis } \\
\text { (line) }\end{array}$ & $\begin{array}{l}\text { alam lumah } \\
\text { (field) }\end{array}$ & $\begin{array}{l}\text { alam jirim } \\
\text { (volume) }\end{array}$ & $\begin{array}{c}\text { alam kajaten } \\
\text { (spiritual space) }\end{array}$ \\
\hline & & \multicolumn{3}{|c|}{ finite-dimensional } & $\begin{array}{c}\text { infinite- } \\
\text { dimensional }\end{array}$ \\
\hline & & \multicolumn{3}{|c|}{$\begin{array}{c}\text { matter } \\
\text { (lahiriyah) }\end{array}$} & $\begin{array}{c}\text { energy } \\
\text { (batiniyah) }\end{array}$ \\
\hline & & \multicolumn{3}{|c|}{ La Illaha } & Illallah \\
\hline & \multirow{5}{*}{ 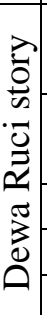 } & $\begin{array}{l}\text { Bima defeat two } \\
\text { giants }\end{array}$ & $\begin{array}{l}\text { Bima met } \\
\text { Hanuman }\end{array}$ & $\begin{array}{l}\text { Bima defeat the } \\
\text { dragon }\end{array}$ & $\begin{array}{l}\text { Bima met } \\
\text { Dewa Ruci }\end{array}$ \\
\hline & & alam garis (line) & $\begin{array}{l}\text { alam lumah } \\
\text { (field) }\end{array}$ & $\begin{array}{c}\text { alam jirim } \\
\text { (volume) }\end{array}$ & alam kajaten \\
\hline & & \multicolumn{3}{|c|}{ material space } & spiritual space \\
\hline & & \multicolumn{3}{|c|}{ matter (lahiriyah) } & energy (batiniyah) \\
\hline & & \multicolumn{3}{|c|}{ La Illaha } & Illallah \\
\hline
\end{tabular}

\section{References}

[No-name]. 1980. Serat Jatimurti. Surabaya: Yayasan UP Djojobojo.

Aryandini S. Woro. 2000. Citra Bima dalam Kebudayaan Jawa. Jakarta: Unversitas Indonesia Press 
Hidayat, Anas. 2002. 'Genesis of Pendapa', Melacak Keberadaan Kolong dalam Arsitektur Jawa. On Proseding Simposium dan Lokakarya Nasional Jelajah Arsitektur Archipelago 2002; Malang, 14 Oktober 2002. Malang: Pustaka Lempana dan Arsitektur Unmer Press. Pages IX-1 - IX-11

Hidayat, Anas. 2009. Ruang Jawa, Ruang Sangkan Paran, Ruang Watak 9. On Proseding Seminar Jelajah Arsitektur Archipelago 2009; Surabaya, 9 Oktober 2009. Surabaya: Arsitektur ITS Press. Pages II-1 - II-18.

Hidayat, Anas. 2010. Anteng Kitiran, Melacak Surasa Kajaten dalam Omah Jawa. On Proseding Seminar Jelajah Arsitektur Archipelago 2010; Surabaya, 11 Oktober 2010. Surabaya: Arsitektur ITS Press. Pages IV-1 - IV-9.

Http: // www.photobucket.com . [downloaded : 10/01/2011]

Mangunwijaya, Y.B. 1992. Sastra dan Religiositas. Yogyakarta: Kanisius.

Nadjib, Emha Ainun. 2005. Kafir Liberal. Jogjakarta: Progress.

Pangarsa, Galih Widjil. 2011. DNA Arsitektur Nias pada Lorong Gravitasi Archipelago Kontemporer. (E-book Engine on arsitekArchipelago.blogspot.com). Malang: @You Publish. [10 Agustus 2011]

Prijotomo, Josef. 2004a. Arsitektur Archipelago, Menuju Keniscayaan. Surabaya: Wastu Lanas Grafika.

Prijotomo, Josef. 2004b. Kembara Kawruh Arsitektur Jawa. Surabaya: Wastu Lanas Grafika.

Rifyal, M.; Munzir, Ahmad; Nofianti, Ayu Ike. 2011. Konsep dan Desain Rumah Gunungan Pancasila. (participating in the contest Suntainable Environmental Architecture 12). Malang: no-publish.

Santosa, Jo. 2009. Arsitektur-Kota Jawa: Kosmos, Kultur \& Kuasa. Jakarta: Centropolis.

Santoso, Revianto B. 2000. Omah: Membaca Makna Rumah Jawa. Yogyakarta: Bentang Budaya. 